\title{
THE USE AND EXCHANGE OF TEACHING MODULES PUBLISHED IN THE SERIES OF HANDBOOKS PREPARED WITHIN THE FRAME OF THE ,FORUM FOR PUBLIC HEALTH IN SOUTH-EASTERN EUROPE“ NETWORK UPORABA IN IZMENJAVA UČNIH MODULOV, OBJAVLJENIH V PRIROČNIKIH MREŽE FORUM ZA JAVNO ZDRAVJE V JUGOVZHODNI EVROPI
}

Lijana Zaletel Kragelj', Luka Kovačič², Vesna Bjegović3, Jadranka Božikov², Genc Burazeri4, Doncho Donev 5 , Adriana Galan ${ }^{6}$, Lidia Georgieva7, Gordana Pavleković2, Silvia Gabriela Scintee ${ }^{8}$, Doris Bardehle ${ }^{9}$, Ulrich Laaser Lin $^{310}$

Prispelo: 28. 11. 2011 - Sprejeto: 21. 5. 2012

Original scientific article UDC 614: 378.147

\section{Abstract}

Aim: Throughout 2004-2010, the series of 6 books entitled "Handbooks for Teachers, Researchers and Health Professionals" were published within the frame of the public health network established in South Eastern Europe (SEE), covering the total of 249 teaching modules. The aim of the study was to assess the use and exchange of these modules between the authors.

Methods: Out of 148 identified authors, 106 took part in the cross-sectional study carried out from July to November 2011 (response rate: 71.6\%). The primary endpoints were the utilization (use and/or exchange) of the modules in general, the percentage of utilized modules from all volumes, the percentages of utilized modules of each volume separately, and the percentage of utilized modules from all the volumes at different levels of the educational process. Non-parametric statistical methods were used for analysis (e.g. Mann-Whitney and Friedman tests).

Results: Module utilization was reported by $80 / 106$ participants (75.5\%). The median value of the percentage of utilized modules from all the volumes was 4.8 , being much higher among full-time university staff $(9.2 ; p=0.008)$ and authors/editors (14.7; $p=0.010$ ). The respondents most frequently utilized Volume 1 (median value: 7.7$)$ and Volume 6 (median value: 4.2$)$ modules $(p=0.002)$ as part of undergraduate (median value: 1.4$)$ and postgraduate vocational (median value: 1.4$)$ study programmes $(p<0.001)$.

Conclusion: The level of module utilization within the group of their authors is good. However, this is only partial information and not representative of the entire target population of SEE public health teachers.

Key words: public health, South-Eastern Europe, education, curriculum, teaching modules use/exchange

Izvirni znanstveni članek

UDK 614: 378.147

\section{Izvleček}

Namen: V okviru javnozdravstvene mreže za jugovzhodno Evropo (JVE) je bila v obdobju 2004-2010 objavljena serija šestih knjig z naslovom Priročniki za učitelje, raziskovalce in zdravstvene delavce. Skupno je bilo objavljenih 249 učnih modulov. Namen študije je bil oceniti uporabo in izmenjavo modulov med avtorji.

\footnotetext{
'Department of Public Health, Medical Faculty, University of Ljubljana, Slovenia

${ }^{2}$ Andrija Stampar School of Public Health, School of Medicine, University of Zagreb, Croatia

${ }^{3}$ University of Belgrade, Faculty of Medicine, Centre School of Public Health, Serbia

${ }^{4}$ Department of International Health, School for Public Health and Primary Care, Faculty of Health, Medicine and Life Sciences, Maastricht

University, The Netherlands

${ }^{5}$ Institute of Social Medicine, Medical Faculty, University Ss Cyril and Methodius, Skopje, Macedonia

${ }^{6}$ Institute of Public Health, Bucharest, Romania

${ }^{7}$ Department of Social medicine and Healthcare management, Medical Faculty, Medical University Sofia, Bulgaria

${ }^{8}$ National School of Public Health, Management and Professional Development, Bucharest, Romania

${ }^{9}$ Section of Epidemiology and International Public Health, Faculty of Health Sciences, University of Bielefeld, Germany

${ }^{10}$ Section of International Public Health, Faculty of Health Sciences, University of Bielefeld, Germany

Correspondence to: e-mail: Lijana.Zaletel-Kragelj@mf.uni-lj.si
} 


\begin{abstract}
Metode: V presečni raziskavi, ki je bila izvedena v obdobju julij-november 2011, je sodelovalo 106 od 148 vabljenih avtorjev (71,6-odstotna odzivnost). Glavni opazovani pojavi so bili: uporaba/izmenjava modulov na splošno, odstotek uporabljanih/izmenjanih modulov iz vseh knjig, odstotek uporabljanih/izmenjanih modulov za vsako knjigo posebej in odstotek uporabljanih/izmenjanih modulov iz vseh knjig na različnih stopnjah izobraževalnega procesa. Za analizo smo uporabili neparametrične statistične metode (Mann Whitney in Friedmanov test).

Rezultati: 80/106 udeležencev (75,5 \%) je poročalo, da uporabljajo/izmenjujejo module. Med njimi je bila mediana odstotka uporabljanih/izmenjanih modulov iz vseh knjig 4,8. Le-ta je bila precej višja med polno zaposlenim univerzitetnim osebjem (9,2: $p=0,008)$ in avtoril/uredniki $(14,7 ; p=0,010)$. Ti anketiranci najpogosteje uporabljajo/ izmenjujejo module prve (mediana: 7,7$)$ in šeste knjige (mediana: 4,2$)(p=0,002)$. Najpogosteje jih uporabljajo na dodiplomskih (mediana: 1,4$)$ in podiplomskih strokovnih študijskih programih (mediana: 1,4) $(p<0,001)$.

Zaključki: Uporaba modulov v skupini njihovih avtorjev je dobra, vendar pa je to le delna informacija o uporabi modulov $v$ ciljni populaciji učiteljev javnega zdravja $v$ JVE.
\end{abstract}

Ključne besede: javno zdravje, jugovzhodna Evropa, uporaba/izmenjava učnih modulov

\section{INTRODUCTION}

After the collapse of the South-East European (SEE) political systems in the early 1990s, the healthcare systems established in this region began to break down under the weight of the transition. At the time, the public health $(\mathrm{PH})$ profession, which only started its transformation from the classical $\mathrm{PH}$, consisting of Epidemiology, Hygiene and Social Medicine, to the new reformed $\mathrm{PH}$, also found itself in an extremely unenviable position. In fact, at that time $\mathrm{PH}$ activities were insufficient in many of the SEE countries. Above all, there was a lack of competence, not only in health management and strategic development, but also in the fields of health surveillance and prevention $(1,2)$. Many $\mathrm{PH}$ issues faced within the SEE region could be resolved to a great extent by reinforcing the cooperation between the SEE countries in this particular field of expertise, especially in the field of education, training and research. Unfortunately, this solution was not so bluntly obvious to those SEE countries burdened with far greater transition-related problems. However, with considerable help from the outside - specifically from the University of Bielefeld School of Public Health, Germany - the re-establishment of this cooperation started in 2000 when the project "Public Health Collaboration in South-Eastern Europe" (PH-SEE) was launched within the frame of the Stability Pact (2000-2005) (1, 3, 4). The Project was supported by the German Academic Exchange Service (DAAD Deutscher Akademischer Austauschdienst) (1). The coordinative role was assigned to the University of Bielefeld School of Public Health, Germany, and the Andrija Stampar School of Public Health, School of Medicine, University of Zagreb, Croatia. In order to sustain the cooperation upon the end of this project, the agreement on the establishment of the multilateral
"Forum for Public Health in South-Eastern Europe" network (FPH-SEE) was reached in spring 2006 (2, 5). The efforts to sustain the Network were further supported throughout 2008-2010 by the MetaNet-SEE Project funded by $\operatorname{DAAD}(6,7)$. The coordinative role was assigned to the University of Bielefeld School of Public Health, Germany (6). Almost concurrently, the SEE networking in the field of $\mathrm{PH}$ was also supported by the Public Health Research Network Project coordinated by the Maastricht University, Department of International Health, Maastricht, the Netherlands (7, 8). In 2011, the Network was supported by the DAADfunded project "The Visibility of Public Health Teaching and Research in South-East Europe", coordinated by the Charite-Universitätsmedizin Berlin, Berlin School of Public Health, Berlin, Germany.

One of the main objectives of the PH-SEE and the pertaining successive projects was to support capacity building through the reinforcement of postgraduate $\mathrm{PH}$ training. This was planned to be achieved through the development of teaching materials (modules) written in English, tailored for the SEE region in line with the $\mathrm{PH}$ developments witnessed on the international scale. To that effect, the curriculum entitled "Curriculum for Health Sciences in South-Eastern Europe Training Programmes for Practice \& Research in Public Health" (hereinafter referred to as "the Curriculum") was developed $(1,9)$. The Curriculum was the result of the joint efforts of $\mathrm{PH}$ teachers from various training and research institutions, predominantly from SEE countries, who were willing and able to participate (in some cases, the language barrier posed as a hindrance or a limiting factor). The main aim was to support and improve the quality of postgraduate $\mathrm{PH}$ training based on specific health and training needs recognized in the SEE countries. The original Curriculum consisted of ten units, each comprising a number of related topics (Table 1). 
Table 1. Ten units and corresponding topics embraced by the original "Curriculum for Health Sciences in SouthEastern Europe Training Programmes for Practice \& Research in Public Health", developed within the frame of the "Forum for Public Health in South-Eastern Europe" network $(1,9)$.

Preglednica 1. Deset enot in ustreznih tem prvotnega Učnega programa za znanosti o zdravju v programih usposabljanja za prakso in raziskave na področju javnega zdravja $v$ Jugovzhodni Evropi, razvitih v okviru mreže Forum za javno zdravje v Jugovzhodni Evropi $(1,9)$.

\section{\begin{tabular}{l}
\hline Unit/Topic \\
\hline I. Introduction to health sciences and public health
\end{tabular}}

1. The history of public health

2. The development of public health in South Eastern Europe

II. Theoretical foundations of health sciences
1. Medical foundations
2. Psychological foundations
3. Sociological foundations

III. Methods and tools in health sciences
1. Statistical methods
2. Epidemiological methods
3. IT and communication technologies
4. Sociological methods
5. Educational methods

IV. Determinants of health
1. Genetic determinants of health
2. Social determinants of health
3. Environmental determinants of health
4. Occupational determinants of health
5. Behavioural determinants of health

V. Disease prevention and health promotion
1. Epidemiology of health and disease
2. Health promotion
3. Healthy settings
4. Social inequality and health
5. Health surveillance
6. Public health interventions

VI. Healthcare and health services
1. Primary healthcare
2. Outpatient services
3. Hospital services
4. Public health services
5. Mental health services
6. Rehabilitative services
7. Public health nursing care
8. Self-help and mutual help
9. Alternative medicine

\section{Enota/Tema}

I. Uvod v znanosti o zdravju in javno zdravje
1. Zgodovina javnega zdravja
2. Razvoj javnega zdravja v Jugovzhodni Evropi

II. Teoretični temelji znanosti o zdravju
1. Medicinski temelji
2. Psihološki temelji
3. sociološki temelji

III. Metode in orodja v znanostih o zdravju
1. Statistične metode
2. Epidemiološke metode
3. Informatika in komunikacijske tehnologije
4. Sociološke metode
5. Izobraževalne metode

IV. Determinante zdravja

1. Genetske determinante zdravja

2. Socialne determinante zdravja

3. Okoljske determinante zdravja

4. zaposlitvene determinante zdravja

5. Vedenjske determinante zdravja

V. Preprečevanje bolezni in promocija zdravja

1. Epidemiologija zdravja in bolezni

2. Promocija zdravja

3. Zdravju naklonjena okolja

4. Socialna neenakost in zdravje

5. Zdravstveni nadzor

6. Javnozdravstveni ukrepi

VI. Zdravstveno varstvo in zdravstvena dejavnost

1. Primarno zdravstveno varstvo

2. Ambulantna dejavnost

3. Bolnišnična dejavnost

4. Javnozdravstveni dejavnost

5. Dejavnost duševnega zdravja

6. Rehabilitacijska dejavnost

7. javnozdravstveni nega

8. samopomoč in vzajemna pomoč

9. Alternativna medicina 
VII. Health management
1. Health policy
2. Health regulations
3. Health economics
4. Healthcare management
5. Quality assurance

VIII. Public health strategy

1. Health needs assessment

2. Programme planning

3. Programme implementation

4. Evaluation

5. Ethics in Public Health

IX. International health

1. International health organisations

2. Health care reform

3. Global health inequalities

4. Migration and health

5. Peace and public health

X. Appendices
1. Public health documents
2. Public health glossaries

VII. Upravljanje in vodenje zdravstvenih sistemov
1. Politika zdravja
2. zdravstvena zakonodaja
3. Zdravstvena ekonomika
4. Vodenje zdravstvenih inštitucij
5. Zagotavljanje kakovosti

VIII. Javnozdravstvene strategije

1. Ocenjevanje potreb po zdravju

2. načrtovanje programov

3. Izvajanje programov

4. Vrednotenje

5. Etika v javnem zdravju

IX. Mednarodno zdravje

1. Mednarodne zdravstvene organizacije

2. Reforma zdravstvenega varstva

3. Globalne neenakosti v zdravju

4. Migracije in zdravje

5. Mir in javno zdravje

X. Priloge

1. Javnozdravstveni dokumenti

2. Javnozdravstveni geslovniki
For each topic, one or more training modules of varying length were supposed to be available during the continuous developmental process. These modules were intended to be a collection of teaching ideas that could be exchanged between $\mathrm{PH}$ teachers in SEE in postgraduate training programmes and/or the continuous education of $\mathrm{PH}$ professionals, and were prepared to allow any given teacher to use them in his/ her own teaching practice. They were originally planned to be on the Internet platform only (1) and were initially stored on website of the Andrija Stampar School of
Public Health (5). Within the PH-SEE, FPH-SEE and MetaNet projects, and in agreement with the Hans Jacobs Publishing Company, it was later decided to publish this training material as hard copy books - i.e. as a series of books entitled "Handbooks for Teachers, Researchers and Health Professionals". So far, six volumes have been issued, edited by 8 different editors and 3 editorial assistants (10-15). The first volume was issued in 2004 and the last in 2010. These volumes comprise a total of 249 teaching modules (Table 2). 
Table 2. Characteristics of the six volumes of the "Handbooks for Teachers, Researchers and Health Professionals", published within the frame of the "Forum for Public Health in South-Eastern Europe" network.

Preglednica 2. Značilnosti šestih knjig serije Priročniki za učitelje, raziskovalce in zdravstvene delavce, izdanih $v$ okviru mreže Forum za javno zdravje v Jugovzhodni Evropi $(1,9)$.

\begin{tabular}{|c|c|c|c|c|c|}
\hline $\begin{array}{l}\text { Volume } \\
\text { Knjiga }\end{array}$ & $\begin{array}{l}\text { Title } \\
\text { Naslov }\end{array}$ & $\begin{array}{c}\text { Year of } \\
\text { publication } \\
\text { Leto izida }\end{array}$ & $\begin{array}{c}\text { No. of } \\
\text { modules } \\
\text { Število } \\
\text { modulov }\end{array}$ & $\begin{array}{l}\text { Unit of the curriculum* } \\
\text { covered } \\
\text { Odgovarjajoča enota } \\
\text { učnega programa* }\end{array}$ & $\begin{array}{l}\text { Editors } \\
\text { Uredniki }\end{array}$ \\
\hline \multirow[t]{2}{*}{1} & $\begin{array}{l}\text { Health Systems and their Evidence } \\
\text { Based Development (10) }\end{array}$ & 2004 & 26 & VIII. Health management & $\begin{array}{l}\text { Bjegovic V } \\
\text { Donev D }\end{array}$ \\
\hline & $\begin{array}{l}\text { Zdravstveni sistemi in njihovih na } \\
\text { dokazih temelječ razvoj (10) }\end{array}$ & & & $\begin{array}{l}\text { VII. Upravljanje in vodenje } \\
\text { zdravstvenih sistemov }\end{array}$ & \\
\hline \multirow[t]{2}{*}{2} & $\begin{array}{l}\text { Public Health Strategies: A Tool For } \\
\text { Regional Development (11) }\end{array}$ & 2005 & 39 & VIII. Public health strategy & $\begin{array}{l}\text { Galan A } \\
\text { Scintee SG }\end{array}$ \\
\hline & $\begin{array}{l}\text { Javnozdravstvene strategije: orodje } \\
\text { za regionalni razvoj (11) }\end{array}$ & & & $\begin{array}{l}\text { VIII. Javnozdravstvene } \\
\text { strategije }\end{array}$ & \\
\hline \multirow[t]{2}{*}{3} & $\begin{array}{l}\text { Health Determinants in the Scope of } \\
\text { New Public Health (12) }\end{array}$ & 2005 & 28 & $\begin{array}{l}\text { IV. Determinants of } \\
\text { health }\end{array}$ & $\begin{array}{l}\text { Burazeri G } \\
\text { Georgieva L }\end{array}$ \\
\hline & $\begin{array}{l}\text { Determinante zdravja na področju } \\
\text { novega javnega zdravja (12) }\end{array}$ & & & IV. Determinante zdravja & \\
\hline \multirow[t]{2}{*}{4} & $\begin{array}{l}\text { Health Promotion and Disease } \\
\text { Prevention (13) }\end{array}$ & 2007 & 64 & $\begin{array}{l}\text { Disease prevention } \\
\text { and health promotion }\end{array}$ & $\begin{array}{l}\text { Donev D } \\
\text { Pavlekovic G } \\
\text { Zaletel-Kragelj L }\end{array}$ \\
\hline & $\begin{array}{l}\text { Promocija zdravja in preprečevanje } \\
\text { bolezni (13) }\end{array}$ & & & $\begin{array}{l}\text { V. Preprečevanje } \\
\text { bolezni in promocija } \\
\text { zdravja }\end{array}$ & \\
\hline \multirow[t]{2}{*}{5} & $\begin{array}{l}\text { Management in Health Care Practice } \\
\text { (14) }\end{array}$ & 2008 & 45 & $\begin{array}{l}\text { VI. Health care and } \\
\text { health services }\end{array}$ & $\begin{array}{l}\text { Kovacic L } \\
\text { Zaletel-Kragelj L }\end{array}$ \\
\hline & $\begin{array}{l}\text { Management v zdravstveni praksi } \\
\text { (14) }\end{array}$ & & & $\begin{array}{l}\text { VI. Zdravstveno varstvo in } \\
\text { zdravstvena dejavnost }\end{array}$ & \\
\hline \multirow[t]{2}{*}{6} & $\begin{array}{l}\text { Methods and Tools in Public Health } \\
\text { (15) }\end{array}$ & 2010 & 47 & $\begin{array}{l}\text { III. Methods and tools in } \\
\text { health sciences }\end{array}$ & $\begin{array}{l}\text { Zaletel-Kragelj L } \\
\text { Bozikov J }\end{array}$ \\
\hline & $\begin{array}{l}\text { Metode in orodja v javnem zdravju } \\
\text { (15) }\end{array}$ & & & $\begin{array}{l}\text { III. Metode in orodja v } \\
\text { znanostih o zdravju }\end{array}$ & \\
\hline
\end{tabular}

* - Curriculum for Health Sciences in South-Eastern Europe Training Programmes for Practice \& Research in Public Health (1).

* - Učni program za znanosti o zdravju v programih usposabljanja za prakso in raziskave na področju javnega zdravja v Jugovzhodni Evropi (1).

Aiming to assess the utilization of the modules published in the volumes discussed above across the target SEE public health teaching population, the objective of the present study was to assess the use and exchange of modules published in these volumes among authors based in the SEE countries that participate in the FPHSEE network. 


\section{MATERIAL AND METHODS}

A cross-sectional study making use of a selfadministered questionnaire was carried out from July to November 2011.

The target population was module authors from 11 SEE countries participating in the FPH-SEE network (Albania, Bosnia \& Herzegovina, Bulgaria, Croatia, Kosovo, Macedonia, Moldova, Montenegro, Romania, Serbia and Slovenia). Authors coming from other countries (Germany, Canada, Hungary, the Netherlands, Switzerland, Turkey, UK and USA) or international organizations (the European Community and the World Health Organization) were excluded from the study. A total of 161 authors were identified (Albania: 3, Bosnia \& Herzegovina: 4, Bulgaria: 22, Croatia: 22 , Kosovo: 0, Macedonia: 40, Moldova: 2, Montenegro: 1, Romania: 11, Serbia: 22, and Slovenia: 34).

The study instrument was a questionnaire developed especially for the purposes of this study. It included questions on the participant's teaching status (1-fulltime university or other academic staff, 2-part-time university or other academic staff, 3-non-university academic staff elected to an academic degree but not employed at a university, 4-not teaching anymore, 5-retired and not teaching anymore, 6-have never been teaching. In the analytical phase, an additional category was introduced as well: 7-retired but still teaching). There were also questions on module utilization (use and/or exchange) (1-none, 2-yes but only those authored or co-authored by the participant, 3 -yes, irrespective of the authorship). The editorial status of the respondents (0-author, 1-editor and 2-editorial assistant) was already known. All those confirming the utilization of the modules were further asked about the mode of module utilization (1-utilization of the original teaching module(s) exactly as displayed in the pertaining volume(s), 2-the original text edited to better fit the teaching process, 3-the original text translated for the teaching purposes, 4-the original text translated and edited for teaching purposes), and about the utilization of each of the 249 modules at different educational levels: 1-undergraduate study programme, 2-graduate (master) study programme, 3-vocational postgraduate study programme (socalled "specialistic" study), 4-scientific master study programme, 5-PhD study programme, and 6-lifelong study programme). This was done for each of the 6 volumes separately. The questionnaire was prepared to be completed electronically. It was sent to all 161 identified authors by e-mail. All e-mail addresses were verified by the research team. In order to be able to accurately calculate the response rate, every e-mail was checked for its delivery. All the invited authors were asked to complete the questionnaire electronically and send it back by e-mail to the first author of this paper. The endpoints were the utilization of the modules in general $(0=$ no, $1=y e s)$, the mode of their utilization (1-utilization of the original teaching module(s) exactly as displayed in the pertaining volume(s), 2-the original text translated and/or edited for teaching purposes), the percentage of utilized modules from all 6 volumes, the percentages of utilized modules of each volume separately and the percentage of utilized modules from all 6 volumes at different levels of the educational process.

The utilization of the modules in general was partly observed in the entire responding group and partly in the group of respondents who reported module utilization. The differences between the different groups differentiated based on the respondents' teaching status (for the purposes of analysis, Categories 7 and 3, as well as Categories 4, 5 and 6, were combined), editorial status (for the purposes of analysis, Categories 2 and 3 were combined) and the country of establishment were analysed (countries of establishment with more than 20 authors, that is to say Croatia, Macedonia, Serbia and Slovenia, were analysed separately, while countries of establishment with less than 20 authors, that is to say Albania, Bosnia \& Herzegovina, Bulgaria, Moldova, Montenegro and Romania, were analysed as a group). The Pearson chi-square test was used or, if there expected frequencies were too low in too many cells, its exact analogues were used (e.g. Fisher's exact test or likelihood chi-square test). The analysis of the modules' utilization mode made use of the same methodology. This endpoint was only targeted in the group of respondents who reported module utilization. The percentages of utilized modules from all 6 volumes, from each volume separately, and from all 6 volumes at different educational levels were also observed only in the group of respondents who reported module utilization. Since the distributions of percentage values were not symmetrical, all the observed outcomes were described and analysed using non-parametric statistical methods. The differences in the percentage of utilized modules from all 6 volumes between the responding groups differing in their teaching and editorial status and the country of establishment, were analysed using the Mann-Whitney test. The differences in the percentage of utilized modules published in different volumes and used in the different levels of the educational process, 
were analysed on the level of the whole responding group using the Friedman test. A p-value of $\leq 0.05$ was considered significant at all times. SPSS 18.0 for Windows (SPSS Inc., Chicago, IL) was used for analysis.

\section{RESULTS}

\subsection{Sample Description}

Out of the 161 authors identified as potential study participants, $13(8.1 \%)$ could not be contacted because their e-mail addresses were not available or were obsolete, while new ones could not be obtained (Bulgaria: 3, Croatia: 3, Macedonia: 3, Moldova: 1, Serbia: 3). Thus, 148 questionnaires were delivered and 106 were returned (response rate: $71.6 \%$ ). Moldova and Montenegro failed to respond. The highest response rate was that of Albania (100.0\%) and the lowest was that of Bulgaria (52.6\%). Other countries responded as follows: Bosnia \& Herzegovina: $75.0 \%$, Croatia: $68.4 \%$, Macedonia: $54.1 \%$, Romania: $81.8 \%$, Serbia: $84.2 \%$ and Slovenia: 94.1\%). Among the respondents, 55 $(51.9 \%)$ were full-time university or other academic staff, $13(12.3 \%)$ part-time university or other academic staff, $15(14.2 \%)$ non-university academic staff elected to an academic degree but not employed at the university, $5(4.7 \%)$ fell into the category of those not teaching anymore, $5(4.7 \%)$ were retired and did not teach anymore, $9(8.5 \%)$ have never been teaching and 4 $(3.8 \%)$ were retired but still teaching. The percentage of full-time university or other academic staff among the respondents was highest among the Albania-based $(3 / 3 ; 100.0 \%)$ and the lowest among the Romaniabased respondents $(2 / 9 ; 22.2 \%)$. The share of such staff among the respondents established in other countries was as follows: Bosnia \& Herzegovina (2/3; $66.7 \%)$, Bulgaria (9/10; $90.0 \%)$, Croatia (9/13; $69.2 \%)$, Macedonia (9/20; 45.0\%), Serbia (12/16; 75.0\%) and Slovenia $(9 / 32 ; 28.1 \%)$. All the editors and editorial assistants responded to the survey.

\subsection{Utilization of the Modules in General and the Mode of their Utilization}

Out of the 106 participants, non-utilization of the modules was reported by $26(24.5 \%)$ and utilization by $80(75.5 \%)$ of the respondents. Module utilization displayed by teaching and editorial status, and the country of the respondents' establishment is presented in Table 3.

Out of the group of 80 respondents who reported module utilization, $60(75.0 \%)$ reported their utilization irrespectively of their authorship status, while 20 $(25.0 \%)$ only reported the utilization of the modules authored or a co-authored by themselves. The percentage of those who reported module utilization irrespective of authorship status was significantly higher among the full-time university or other academic staff (44/53; (83.0\%) compared to the part-time university or other academic staff, non-university academic staff and the retired, but still teaching respondents (16/27; $59.3 \%)(p=0.020)$.

Out of the 80 respondents who reported module utilization, $19(23.8 \%)$ reported their utilization only in the original format displayed in the pertaining volume, while $61(76.3 \%)$ reported that the original text had been translated and/or edited to better fit their teaching purposes. Statistically significant differences in the mode of module utilization between authors of different teaching status $(\mathrm{p}=0.378)$, or editorial status $(p=0.723$ ) was not observed, while differences between the authors coming from different countries were close to statistical significance $(p=0.055)$. The percentage of authors who only utilize modules in their original format is higher in Croatia (4/11, 36.4\%) and Slovenia $(7 / 20,35.0 \%)$ than in the other countries (Macedonia: 4/18, 22.2\%; Serbia: 0/13, 0.0\%; Albania, Bosnia \& Herzegovina, Bulgaria, Romania: 4/18, 22.2\%). 
Table 3. Utilization of the modules published in the six volumes of the "Handbooks for Teachers, Researchers and Health Professionals", released within the frame of the "Forum for Public Health in South-Eastern Europe" network, displayed by the respondents' teaching and editorial status, and the country of establishment.

Preglednica 3. Uporaba modulov, objavljenih v šestih knjigah Priročniki za učitelje, raziskovalce in zdravstvene delavce, izdanih v okviru mreže Forum za javno zdravje v Jugovzhodni Evropi glede na stanje poučevanja in urednikovanja avtorjev ter državo iz katere prihajajo.

\begin{tabular}{|c|c|c|c|c|c|}
\hline \multirow[t]{2}{*}{$\begin{array}{l}\text { Population group } \\
\text { Populacijska } \\
\text { skupina }\end{array}$} & & \multicolumn{3}{|c|}{$\begin{array}{l}\text { Utilization of the } \\
\text { modules } \\
\text { Uporaba modulov }\end{array}$} & \multirow[b]{2}{*}{$\mathbf{p}$} \\
\hline & & $\mathbf{N}$ & $\mathbf{N}$ & $\%$ & \\
\hline Teaching status & Full-time university or other academic staff & 55 & 53 & $96.4 \%$ & $<0.001^{*}$ \\
\hline \multirow[t]{5}{*}{ Stanje poučevanja } & Polno zaposleno univerzitetno osebje & & & & \\
\hline & $\begin{array}{l}\text { Part-time university or other academic staff, non-university } \\
\text { academic staff, and retired but still teaching respondents }\end{array}$ & 32 & 27 & $84.4 \%$ & \\
\hline & $\begin{array}{l}\text { Dopolnilno zaposleno univerzitetno osebje, zunanje } \\
\text { habilitirano osebje, upokojeni še vedno aktivni učitelji }\end{array}$ & & & & \\
\hline & $\begin{array}{l}\text { Respondents not teaching any more, retired and not } \\
\text { teaching anymore, and those who have never been teaching }\end{array}$ & 19 & 0 & $0.0 \%$ & \\
\hline & $\begin{array}{l}\text { Avtorii, ki ne učijo več, upokojeni neaktivni učitelji, avtorji, ki } \\
\text { nikoli niso bili učitelji }\end{array}$ & & & & \\
\hline Editorial status & Author and editor or editorial assistant & 13 & 13 & $100.0 \%$ & $0.035^{\#}$ \\
\hline \multirow[t]{3}{*}{ Stanje urednikovanja } & Avtor in urednik ali uredniški pomočnik & & & & \\
\hline & Author only & 93 & 67 & $72.0 \%$ & \\
\hline & Avtor & & & & \\
\hline Country & Croatia & 13 & 11 & $84.6 \%$ & $0.164^{*}$ \\
\hline \multirow[t]{8}{*}{ Država } & Hrvaška & & & & \\
\hline & Macedonia & 20 & 18 & $90.0 \%$ & \\
\hline & Makedonija & & & & \\
\hline & Serbia & 16 & 13 & $81.3 \%$ & \\
\hline & Srbija & & & & \\
\hline & Slovenia & 32 & 20 & $62.5 \%$ & \\
\hline & Slovenija & & & & \\
\hline & $\begin{array}{l}\text { Albania, Bosnia \& Herzegovina, Bulgaria, Romania } \\
\text { Albanija, Bosna in Hercegovina, Bolgarija, Romunija }\end{array}$ & 25 & 18 & $72.0 \%$ & \\
\hline
\end{tabular}

LEGEND: * - Likelihood ratio test; \# - Fisher's Exact Test

LEGENDA: * - Test razmerja verjetij; \# - Fisherjev natančni test

\subsection{Percentage of Modules Utilized}

Among the respondents reporting module utilization, the median value of the utilization percentage of all 249 modules was 4.8. The median value was much higher among the full-time university or other academic staff, as well as among the authors concurrently acting as editors or editorial assistants (Table 4). The highest median value was observed among the Albania-, Bosnia \& Herzegovina-, Bulgaria- and Romania-based respondents, while the lowest was obtained among the Slovenian respondents. These differences were unanimously statistically significant (Table 4). 
Table 4. The typical values of distribution of percentage of utilized modules from all 249 modules published in the six volumes of the "Handbooks for Teachers, Researchers and Health Professionals", released within the frame of the "Forum for Public Health in South-Eastern Europe" network, established among the respondents who reported module utilization, displayed by their teaching and editorial status, and the country of establishment, together with the results of the Mann-Whitney test.

Preglednica 4. Tipične vrednosti odstotka uporabljenih modulov od vseh 249 modulov iz vseh šestih knjig iz serije Priročniki za učitelje, raziskovalce in zdravstvene delavce, izdanih v okviru mreže Forum za javno zdravje $v$ Jugovzhodni Evropi, v celotni skupini respondentov, ki so poročali, da uporabljajo module in glede na stanje poučevanja in urednikovanja avtorjev ter državo iz katere prihajajo z rezultati Mann Whitneyevega testa.

\begin{tabular}{|c|c|c|c|c|c|c|c|c|c|}
\hline \multirow{2}{*}{$\begin{array}{l}\text { Population } \\
\text { group } \\
\text { Populacijska } \\
\text { skupina }\end{array}$} & & \multicolumn{7}{|c|}{$\begin{array}{c}\text { Typical value } \\
\text { Tipična vrednost }\end{array}$} & \multirow[b]{2}{*}{$\mathbf{p}$} \\
\hline & & \multirow{2}{*}{$\begin{array}{l}\mathbf{N} \\
80\end{array}$} & \multirow{2}{*}{$\begin{array}{l}\text { Min } \\
0.4\end{array}$} & \multirow{2}{*}{$\begin{array}{r}\mathbf{Q}_{1} \\
1.6\end{array}$} & \multirow{2}{*}{$\begin{array}{l}\text { Me } \\
4.8\end{array}$} & \multirow{2}{*}{$\frac{\mathbf{Q}_{3}}{14.6}$} & \multirow{2}{*}{$\begin{array}{l}\text { Max } \\
99.6\end{array}$} & $\begin{array}{l}\text { Mean } \\
\text { rank }\end{array}$ & \\
\hline $\begin{array}{l}\text { Total group } \\
\text { Celotna skupina }\end{array}$ & & & & & & & & & \\
\hline \multirow{2}{*}{$\begin{array}{l}\text { Celotna skupina } \\
\text { Teaching } \\
\text { status } \\
\text { Stanje } \\
\text { poučevanja }\end{array}$} & $\begin{array}{l}\text { Full-time university or other academic staff } \\
\text { Polno zaposleno univerzitetno osebje }\end{array}$ & 53 & 0.4 & 2.4 & 9.2 & 20.5 & 85.5 & 45.4 & 0.008 \\
\hline & $\begin{array}{l}\text { Part-time university or other academic staff, } \\
\text { non-university academic staff, and retired } \\
\text { but still teaching respondents } \\
\text { Dopolnilno zaposleno univerzitetno } \\
\text { osebje, zunanje habilitirano osebje, } \\
\text { upokojeni še vedno aktivni učitelji }\end{array}$ & 27 & 0.4 & 0.8 & 2.4 & 8.0 & 99.6 & 30.9 & \\
\hline Editorial status & $\begin{array}{l}\text { Author and editor or editorial assistant } \\
\text { Avtor in urednik ali uredniški pomočnik }\end{array}$ & 13 & 2.8 & 4.8 & 14.9 & 21.9 & 85.5 & 55.6 & 0.010 \\
\hline $\begin{array}{l}\text { Stanje } \\
\text { urednikovanja }\end{array}$ & $\begin{array}{l}\text { Author only } \\
\text { Avtor }\end{array}$ & 67 & 0.4 & 1.2 & 3.6 & 12.8 & 99.6 & 37.6 & \\
\hline \multirow[t]{5}{*}{ Država } & $\begin{array}{l}\text { Croatia } \\
\text { Hrvaška }\end{array}$ & 11 & 0.4 & 0.4 & 4.4 & 9.2 & 20.1 & 33.4 & 0.040 \\
\hline & $\begin{array}{l}\text { Macedonia } \\
\text { Makedonija }\end{array}$ & 18 & 0.4 & 1.5 & 2.8 & 17.5 & 99.6 & 38.6 & \\
\hline & $\begin{array}{l}\text { Serbia } \\
\text { Srbija }\end{array}$ & 13 & 1.2 & 3.2 & 4.4 & 21.9 & 64.3 & 45.2 & \\
\hline & $\begin{array}{l}\text { Slovenia } \\
\text { Slovenija }\end{array}$ & 20 & 0.4 & 0.5 & 2.2 & 9.8 & 33.3 & 31.6 & \\
\hline & $\begin{array}{l}\text { Albania, Bosnia \& Herzegovina, Bulgaria, } \\
\text { Romania } \\
\text { Albanija, Bosna in Hercegovina, Bolgarija, } \\
\text { Romunija }\end{array}$ & 18 & 0.4 & 8.2 & 13.2 & 23.5 & 27.7 & 53.2 & \\
\hline
\end{tabular}

LEGEND: N - number of respondents; Min - minimal value; Max - maximal value; Me - median value; Q1 - 1st quartile value; $Q 3$ - 3rd quartile value

LEGENDA: N - število respondentov; Min - najmanjša vrednost; Max - največja vrednost; Me - mediana; Q1 - 1. kvartil; Q3 - 3. kvartil 
The analysis of the differences in the percentage of utilized modules of different volumes showed that respondents who reported module utilization most frequently use the modules displayed in Volume 1 (median value: 7.7 ). The second most utilized volume was Volume 6 (median value: 4.2). All the other typical values and results of the analysis of intra-group differences are presented in Table 5.
The analysis of the differences in the percentage of utilized modules at different educational levels showed that respondents utilising the modules most frequently use them as a part of the undergraduate (median value: 1.4) and postgraduate vocational curricula (median value: 1.4$)$. All the other typical values and the results of the analysis of intra-group differences are presented in Table 6.

Table 5. The typical values of distribution of percentage of utilized modules displayed in each of the six volumes of the "Handbooks for Teachers, Researchers and Health Professionals", released within the frame of the "Forum for Public Health in South-Eastern Europe" network, together with the results of Friedman test.

Preglednica 5. Tipične vrednosti odstotka uporabljenih modulov vsake od šestih knjig iz serije Priročniki za učitelje, raziskovalce in zdravstvene delavce, izdanih v okviru mreže Forum za javno zdravje v Jugovzhodni Evropi, z rezultati Friedmanovega testa.

\begin{tabular}{|c|c|c|c|c|c|c|c|}
\hline \multirow{3}{*}{$\begin{array}{l}\text { Typical value } \\
\text { Tipična vrednost }\end{array}$} & \multicolumn{6}{|c|}{ Volume } & \multirow[b]{3}{*}{$p$} \\
\hline & \multicolumn{6}{|c|}{ Knjiga } & \\
\hline & 1 & 2 & 3 & 4 & 5 & 6 & \\
\hline $\mathrm{N}$ & 80 & 80 & 80 & 80 & 80 & 80 & 0.002 \\
\hline Min & 0.0 & 0.0 & 0.0 & 0.0 & 0.0 & 0.0 & \\
\hline$Q_{1}$ & 0.0 & 0.0 & 0.0 & 0.0 & 0.0 & 0.0 & \\
\hline $\mathrm{Me}$ & 7.7 & 2.6 & 1.8 & 3.1 & 3.3 & 4.2 & \\
\hline$Q_{3}$ & 30.8 & 12.8 & 14.3 & 14.1 & 15.6 & 14.9 & \\
\hline Max & 100.0 & 100.0 & 100.0 & 100.0 & 100.0 & 97.9 & \\
\hline Mean rank & 4.0 & 3.2 & 3.1 & 3.5 & 3.4 & 3.8 & \\
\hline
\end{tabular}

LEGEND: N - number of respondents; Min - minimal value; Max - maximal value; Me - median value; Q1 - 1st quartile value; Q3 - 3rd quartile value

LEGENDA: N - število respondentov; Min - najmanjša vrednost; Max - največja vrednost; Me - mediana; Q1 - 1. kvartil; Q3 - 3. kvartil; Mean rank - povprečni rang 
Table 6. The typical values of distribution of percentage of the utilized modules published in the six volumes of the "Handbooks for Teachers, Researchers and Health Professionals", released within the frame of the "Forum for Public Health in South-Eastern Europe" network, seen at different educational levels, together with the results of the Friedman test.

Preglednica 6. Tipične vrednosti odstotka uporabljenih modulov od vseh 249 modulov iz vseh šestih knjig iz serije Priročniki za učitelje, raziskovalce in zdravstvene delavce, izdanih v okviru mreže Forum za javno zdravje $v$ Jugovzhodni Evropi, na različnih ravneh izobraževalnega procesa z rezultati Friedmanovega testa.

\begin{tabular}{|c|c|c|c|c|c|c|c|}
\hline \multirow[b]{2}{*}{$\begin{array}{l}\text { Typical value } \\
\text { Tipična vrednost }\end{array}$} & \multicolumn{6}{|c|}{$\begin{array}{c}\text { Educational programme level } \\
\text { Raven izobraževalnega programa }\end{array}$} & \multirow[b]{2}{*}{$p$} \\
\hline & $\begin{array}{c}\text { Under- } \\
\text { graduate } \\
\text { Dodiplomska }\end{array}$ & $\begin{array}{c}\text { Graduate } \\
\text { (master) } \\
\text { Diplomska } \\
\text { (bolonjski } \\
\text { magisterij) }\end{array}$ & $\begin{array}{c}\text { Post-graduate } \\
\text { - vocational } \\
\text { (specialist) } \\
\text { Podiplomska - } \\
\text { strokovna } \\
\text { (specializacija) }\end{array}$ & $\begin{array}{c}\text { Post- } \\
\text { graduate- } \\
\text { scientific } \\
\text { master } \\
\text { Podiplomska } \\
\text { - magisterij } \\
\text { znanosti }\end{array}$ & $\begin{array}{c}\text { Post- } \\
\text { graduate - } \\
\text { PhD } \\
\text { Podiplomska } \\
\text { - doktorat } \\
\text { znanosti }\end{array}$ & $\begin{array}{l}\text { Life-long } \\
\text { learning } \\
\text { Vse- } \\
\text { življenjsko } \\
\text { učenje }\end{array}$ & \\
\hline $\mathrm{N}$ & 80 & 80 & 80 & 80 & 80 & 80 & $<0.001$ \\
\hline Min & 0.0 & 0.0 & 0.0 & 0.0 & 0.0 & 0.0 & \\
\hline$Q_{1}$ & 0.0 & 0.0 & 0.0 & 0.0 & 0.0 & 0.0 & \\
\hline $\mathrm{Me}$ & 1.4 & 0.2 & 1.4 & 0.0 & 0.0 & 0.0 & \\
\hline $\mathrm{Q}_{3}$ & 8.5 & 3.0 & 8.6 & 2.4 & 2.0 & 0.3 & \\
\hline Max & 97.6 & 98.0 & 94.0 & 91.2 & 55.0 & 36.5 & \\
\hline Mean rank & 4.3 & 3.5 & 4.1 & 3.3 & 3.1 & 2.6 & \\
\hline
\end{tabular}

LEGEND: $\mathrm{N}$ - number of respondents; Min - minimal value; Max - maximal value; Me - median value; Q1 - 1st quartile value; $\mathrm{Q} 3$ - 3rd quartile value

LEGENDA: N - število respondentov; Min - najmanjša vrednost; Max - največja vrednost; Me - mediana; Q1 - 1. kvartil; Q3 - 3. kvartil; Mean rank - povprečni rang

\section{DISCUSSION}

The results of our study showed that the rough utilization of the modules within the group of their authors was good. The modules are most utilised by the full-time university or other academic staff. Such a result is understandable since the authors involved in the educational process needs to cover different topics and consequently many modules are useful to them. Module utilisation is also satisfactory among the part-time university or other academic staff, as well as among non-university academic staff and retired but still teaching authors. All the other authors, who have never been or ceased to be involved in the educational process, did not utilise the modules. Most of them were retired full-time university or other academic staff members. As expected due to their strongest motivation and active involvement in the preparation of the volumes under consideration, the authors/editors or editorial assistants unanimously reported module utilisation.
The majority of authors translated and/or edited the original module texts to better fit their teaching needs. This result is mainly due to the fact that the authors actually translated their existing training modules from their mother tongues into English for the purposes of the Handbook series publication. When it comes to the teaching process, they tend to use them in their native languages. Editing can also be explained. The texts published in the volumes under consideration are not suitable for all educational levels, so that they needed to be edited to a greater or lesser degree.

The results of the percentage of utilized modules of all volumes were similar to the rough utilization - it was highest among the full-time university or other academic staff and among authors/editors or editorial assistants. The reasons have already been discussed. The percentage in reference was highest among the group of authors coming from several countries processed as a single group and lowest among the Slovenian authors. However, this result is difficult to comment on. 
The analysis of the differences in the percentage of utilized modules of different volumes showed that the respondents who reported module utilization most frequently use modules appearing in Volumes 1 and 6. The first result was expected, since the Volume 1 has already been in use for several years. However, the second result came as a surprise. The last volume was only distributed among potential users in spring 2011. This could indicate that the topics most needed in the SEE region are the topics addressing various methodological PH approaches.

The analysis of the differences in the percentage of utilized modules at different educational levels showed that the respondents who reported module utilization most frequently use them as part of undergraduate and postgraduate vocational curricula, although these modules were originally meant to be used as a part of the master and lifelong learning curricula. This phenomenon is both easy and rather difficult to explain, since it is influenced by a number of factors. Firstly, this result certainly mirrors the impact of the changes to the educational process that affects the entire European region. The Curriculum was developed before the process of transformation started by the Bologna Declaration $(1,9)$. This process started in 2001 and lasted until 2010. This means that the FPH-SEE books were released in the middle of this process. Even more so, within the 2004-2010 timeframe, the most dynamic transformation took place. In many countries, this process was politically driven, leaving academic institutions with no time to become aware of all the possible consequences. In line with the foregoing, this process can be described as a quite chaotic one, with the majority of issues not yet being solved. At the moment the old programmes are disappearing (e.g. old postgraduate scientific Masters) and new ones are not yet fully established, which goes especially for the Bologna Masters programmes. Consequently, the modules cannot often be used at these educational levels. Secondly, PH in SEE countries is traditionally linked to medicine. Consequently, most of the $\mathrm{PH}$ professionals performing in the SEE region are medical doctors specializing in $\mathrm{PH}$. Thus it is understandable that the modules under consideration are most frequently used as part of undergraduate medical studies and vocational postgraduate study programmes designed for medical doctors. These two study tracks have also managed to stay virtually untouched by the Bologna process taking place in the region. However, medical studies are no longer treated as undergraduate, but as unified masters programmes. From this point of view, the modules are somehow mostly utilized at the target educational level. Finally, we didn't collect information on the educational levels the authors are operating on. Therefore, the result obtained is likely to be biased, at least to a certain extent, because the respondents are not unanimously involved in all the levels of the educational process.

This study has some potential limitations. Firstly, it only embraced the module authors. If we were to assess the utilization of materials in the total target population of $\mathrm{PH}$ teachers performing in the SEE, this could pose as an important bias. However, in order to perform a larger study involving all the potential users of the modules, we would first need to establish a meaningful and proper sampling frame. For example, all the countries participating in the FPH-SEE Network should first identify all the institutions in which modules could potentially be used, including the National PH institutes where the modules could be used as a part of lifelong learning programmes. In the next step, the potential users operating within these institutions should be identified. This identification would be both time-consuming and demanding. Additionally, not all the authors could be contacted. It seems that some authors contributed to the books but afterwards somehow disappeared and became unavailable together with their e-mail addresses. Almost all of these authors were co-authors invited to participate by the first authors and the researchers involved in this study didn't have their e-mail addresses since they were not listed as contact persons. Only one was a first author who abandoned the $\mathrm{PH}$ profession and could not be contacted by the data collection closure date. The researchers tried to obtain the addresses of these coauthors by contacting the first authors, but unfortunately were not fully successful. When it comes to the module authors, one can also express one's concern about the limited number of authors participating in the module writing (only a few authors or none from Albania, Bosnia \& Herzegovina, Moldova, and Montenegro). However, this problem is not related to this survey; this is a larger scale issue of motivating $\mathrm{PH}$ teachers to participate as FPH-SEE module authors. For example, only $3 \mathrm{PH}$ teachers from Albania were willing (or able) to participate in this venture. In any case, this does not mean that 3 $\mathrm{PH}$ teachers is everything Albania has to offer, or that the School of PH established there depends on just 3 teachers. Secondly, one can express one's concern that latest developments in $\mathrm{PH}$ subspecialties and sub-areas were not adequately taken into account by the FPH-SEE series. However, these modules were planned to be available on the Internet platform so they could be easily renewed and upgraded with the latest developments. Thirdly, although the questionnaire was very extensive 
in the sense that information was requested on each of the 249 modules, it lacked some additional information discussed in the previous paragraph. Finally, we didn't analyse which modules or types of modules are most commonly used. This should be discussed and added to the future research on the topic.

However, this study also has several strengths. Firstly, it provides the first insight into the utilization of the published materials. Secondly, it could be treated as a feasibility study preceding a study of larger proportions. It turned out that such a larger study could be quite an endeavour, since the collection of the completed questionnaires was already an issue in the present study. Finally, during the questionnaire preparation process, one could not help noticing that some modules could be better fitted into a volume other than the one they are concurrently placed in. Should a second edition be published, they could be allocated far more suitably, while this second edition could be compiled in an electronic form alone.

No doubt the investment into the preparation and publishing of the FPH-SEE series made by DAAD and the efforts of the editors and authors coming from SEE countries in terms of sharing their expert knowledge and devoting their spare time to this cause, were to the common benefit. However, there is still a lot of work to be done. Firstly, three units of the Curriculum have still not been covered. Secondly, the existing volumes and the modules they contain should be reviewed again. Some modules should be regrouped or, due to overlap or lower quality, even eliminated if necessary. Also, some modules need to be renewed with actual data. English editing is essential as well, since the English in which some of the modules are written is not exactly that of the Queen. Unfortunately, during the preparation of the volumes, resources were not provided for covering translation or proofreading within the project frames, while academic and other SEE institutions of poorer standing could not afford to provide such resources independently.

\section{CONCLUSIONS}

It can be concluded that the investment into the preparation and publishing of the FPH-SEE book series has paid off. Since this study only provides partial information on the utilization of these materials, the survey should be extended to cover all the potential users. To perform such a study, we first need to establish a meaningful and correct sampling frame (the list of all the institutions operating in the SEE countries in which these modules could potentially be used, as well as the list of potential module users affiliated with these institutions).

\section{Acknowledgments}

The authors thank all those authors of the modules published in FPH-SEE books who decided to participate in the study, thus enabling the very first evaluation of the utilization of the published teaching materials. Last but not least, the authors thank all those supporting the FPH-SEE, who made the publication of the "Handbooks for Teachers, Researchers and Health Professionals"series of books possible, which goes especially for the German Academic Exchange Service, DAAD.

\section{References}

1. Kovacic L, Laaser U. Public health training and research collaboration in South Eastern Europe. Med Arh. 200; 55: 13-5.

2. Bjegovic V, Kovacic L, Laaser U. The challenge of public health transition in South Eastern Europe. J Public Health. 2006:184189. Available from: URL: http://www.springerlink.com/content/ gn7v7m71v324x805/fulltext.pdf. Accessed: November 19, 2011.

3. Burazeri G, Laaser U, Bjegovic V, Georgieva L, Consortium for Public Health Collaboration in South Eastern Europe. Regional collaboration in public health training and research among countries of South Eastern Europe. Eur J Public Health. 2005; 15: 97-9. Available from: URL: http://eurpub.oxfordjournals.org/ content/15/1/97.full.pdf+html. Accessed: November 19, 2011.

4. Bardehle D, Laaser U, Zaletel-Kragelj L: Selected indicators on health care resources and health care utilization and costs compared between the countries collaborating in the „Public Health in South Eastern Europe (PH-SEE) network“. Zdrav Var. 2006; 45: 67-80. Available from: URL:http://www.ivz.si/ zv?pi=3\&_3_Filename=attName.png\&_3_Mediald=3079\&_3_ AutoResize=false\&pl=171-3.3. Accessed: November 19, 2011.

5. Forum for Public Health Collaboration in South Eastern Europe, Programmes for Training and Research in Public health - FPHSEE [homepage on the Internet]. Available from: URL: http:// www.snz.unizg.hr/ph-see/index.htm. Accessed: November 19, 2011.

6. MetaNet SEE Project. Network of Academic Networks [homepage on the Internet]. Available from: http://www.snz.hr/ metanet-see. Accessed: November 19, 2011.

7. Donev DM, Galan A, Scintee SG. Contribution to the new public health development in the South Eastern Europe, 20002010. Manag Health. 2010; 14: 26-31. Available from: URL: http://journal.managementinhealth.com/index.php/rms/article/ viewFile/146/368. Accessed: November 19, 2011.

8. Maastricht University, Department of International Health. PHR-NET - Public Health Research Network [homepage on the Internet]. Available from: http://inthealth.eu/research/phrnet-public-health-research-network/. Accessed: November 19, 2011.

9. Forum for Public Health Collaboration in South Eastern Europe, Programmes for Training and Research in Public health - FPHSEE. The Public Health Consortium for South Eastern Europe (PH-SEE). Available from URL: http://www.snz.unizg.hr/ph-see/ news_doc/WHO-COE\%20Flyer.pdf. Accessed: November 19, 2011. 
10. Bjegovic V, Donev D (editors). Health system and their evidence based development. A handbook for teachers, researchers and health professionals. Lage: Hans Jacobs Publishing Company; 2004. Available from: URL: http://www.snz.unizg.hr/ph-see/ publications.htm. Accessed: November 19, 2011.

11. Scintee SG, Galan A (editors). Public health strategies: a tool for regional development. A handbook for teachers, researchers and health professionals. Lage: Hans Jacobs Publishing Company; 2005. Available from: URL: http://www.snz.unizg. hr/ph-see/publications.htm. Accessed: November 19, 2011.

12. Georgieva L, Burazeri G (editors). Health determinants in the scope of new public health. A handbook for teachers, researchers and health professionals. Lage: Hans Jacobs Publishing Company; 2005. Available from: URL: http://www. snz.unizg.hr/ph-see/publications.htm. Accessed: November 19, 2011.
13. Donev D, Pavlekovic G, Zaletel-Kragelj L (editors). Health promotion and disease prevention. A handbook for teachers, researchers and health professionals. Lage: Hans Jacobs Publishing Company; 2007. Available from: URL: http://www. snz.unizg.hr/ph-see/publications.htm. Accessed: November 19, 2011.

14. Kovačić $L$, Zaletel-Kragelj $L$ (editors). Management in health care practice. A handbook for teachers, researchers and health professionals. Lage: Hans Jacobs Publishing Company; 2008. Available from: URL: http://www.snz.unizg.hr/ph-see/ publications.htm. Accessed: November 19, 2011.

15. Zaletel-Kragelj L, Bozikov J (editors). Methods and tools in public health. A handbook for teachers, researchers and health professionals. Lage: Hans Jacobs Publishing Company; 2010. Available from: URL: http://www.snz.unizg.hr/ph-see/ publications.htm. Accessed: November 19, 2011. 